\title{
In vitro irradiation of basement membrane enhances the invasiveness of breast cancer cells
}

\author{
B Paquette ${ }^{*, 1,2}$, C Baptiste', H Therriault ${ }^{1,2}$, G Arguin $^{3}$, B Plouffe $^{4}$ and R Lemay ${ }^{1,2}$ \\ 'Department of nuclear medicine and radiobiology, Faculty of medicine and health sciences, Université de Sherbrooke, 300I 12 th Avenue North, \\ Sherbrooke, Québec, Canada; ${ }^{2}$ Centre de recherche en radiothérapie, CRC-Étienne LeBel, Centre Hospitalier Universitaire de Sherbrooke, 3001 12th \\ Avenue North, Sherbrooke, Québec, Canada; ${ }^{3}$ Department of pharmacology, Faculty of medicine and health sciences, Université de Sherbrooke, 3001 \\ I2th Avenue North, Sherbrooke, Québec, Canada IIH 5N4; ${ }^{4}$ Ottawa Health Research Institute, Moses and Rose Loeb Research Centre, 725 Parkdale \\ Avenue, Ottawa, Ontario, Canada KIY 4 E9
}

Following removal of the primary breast tumour by conservative surgery, patients may still have additional malignant foci scattered throughout the breast. Radiation treatments are not designed to eliminate all these residual cancer cells. Rather, the radiation dose is calculated to optimise long-term results with minimal complications. In a tumour, cancer cells are surrounded by a basement membrane, which plays an important role in the regulation of gene expression. Using an invasion chamber, we have shown that irradiation before cell plating of a reconstituted basement membrane (Matrigel; Becton Dickinson, Bedford, MA, USA) increased the invasiveness of the breast cancer cells MDA-MB-23I. This radiation enhancement of invasion was associated with the upregulation of the pro-invasive gene matrix metalloproteinase (MMP)-2. The expression of membrane type I matrix metalloproteinase (MTIMMP) and tissue inhibitor of metalloproteinase-2 (TIMP), which are required to activate the MMP-2, were also increased. Confirming the role of MMP-2 and MTI-MMP, radiation enhancement of cancer cell invasion was prevented by an MMP-2 inhibitor and an antiMTI-MMP antibody. This study also demonstrated that radiation can potentially enhance the invasion ability by inducing the release of pro-invasive factors stored in the Matrigel. Conversely, no enhancement of invasiveness was observed with the low metastatic cell line MCF-7. This lack of invasiveness correlated with the absence of the MMP-2 activator MTI-MMP in the MCF-7 cells. Radiotherapy is an efficient modality to treat breast cancer which could be further improved by inhibiting the pro-invasive gene upregulated by radiation.

British Journal of Cancer (2007) 97, I505- 1512. doi:I0.1038/sj.bjc.6604072 www.bjcancer.com

Published online 6 November 2007

(c) 2007 Cancer Research UK

Keywords: breast cancer; basement membrane; invasion; matrix metalloproteinase; matrikine; radiation

The efficiency of radiotherapy to treat breast cancer is well established (Clarke et al, 2005). However, the radiation dose used in the clinic $(50-60 \mathrm{~Gy})$ is not calculated to eliminate all cancer cells scattered throughout the breast but rather to optimise longterm results with minimal complications. The three major normal tissue side-effects are cosmetic outcome, cardiac complications and pulmonary fibrosis (Coles et al, 2005). The principal long-term complications that impair cosmetics are fibrosis and induration of the breast resulting from inflammatory responses induced by radiation (Archambeau et al, 1995). The probability of observing late changes by 5 years for patients receiving radiotherapy is about $40 \%$ (Coles et al, 2005).

Following surgery both surgeons and patients are reassured by histological confirmation of complete excision, with clear margins.

\footnotetext{
*Correspondence: Professor B Paquette, Department of Nuclear Medicine and Radiobiology, Faculty of Medicine and Health Sciences, Univérsite de Sherbrooke, 300I 12th Avenue North, Sherbrooke, Québec, Canada JIH 5N4;

E-mail: Benoit.Paquette@USherbrooke.ca

Received 21 August 2007; revised 9 October 2007; accepted 9 October 2007; published online 6 November 2007
}

However, several reports have questioned the accuracy of pathological assessment (Holland et al, 1985; Frazier et al, 1989; Silverstein et al, 1994). In a detailed analysis of mastectomy specimens, it has been shown that malignant foci were found at a distance of $2 \mathrm{~cm}$ from tumour edge in $42 \%$ of specimens (Holland et al, 1985). An other team has reported that residual cancer cells were observed in as many as $26 \%$ of patients reported to have pathological margins clear of tumour (Frazier et al, 1989). Of patients clinically and mammographically suspected of having unifocal breast cancer, $39-63 \%$ will have additional malignant foci in the ipsilateral breast as determined by detailed serial sectioning of the mastectomy specimen (Lagios et al, 1981; Holland et al, 1985).

Consequently, a number of breast cancer cells are not eliminated after surgery and radiotherapy. These residual cancer cells could be responsible for distant metastases associated with death from breast cancer. The overall aim of this study is to determine whether ionising radiation could enhance the invasion capacity of the breast cancer cells that are not eliminated after therapy.

A breast tumour can be divided into five parts: cancer cells, fibroblast, inflammatory cells, blood vessels and the basement membrane. In this study, we want to determine whether irradiation of basement membrane could enhance the invasion ability of breast cancer cells. Basement membrane acts as a barrier 
to cancer cell invasion. To overcome this barrier, advancing cells express proteinases and/or proteinase activators at their leading edge, where complex proteolysis can direct cell migration. Among these proteinases, matrix metalloproteinases (MMPs) are believed to play a major role in tumour invasion since they can degrade almost all the basement membrane macromolecules (Rooprai and McCormick 1997; Fillmore et al, 2001).

Matrix metalloproteinase-2 plays a major role in the proteolysis of basement membrane and is associated with tumour invasion and metastasis (Gilles et al, 1998; Jones et al, 1999). Matrix metalloproteinase- 2 is released by cancer cells or fibroblasts under an inactive form called proMMP-2 (Liotta and Stetler-Stevenson 1991; Belkhiri et al, 1997). Activation of proMMP-2 requires the contribution of a cell membrane MMP (ie membrane type 1 MMP, MT1-MMP) and the tissue inhibitor of metalloproteinase-2 (TIMP2). The catalytic domain of MT1-MMP binds to the N-terminal portion of TIMP-2, leaving the negatively charged C-terminal region of TIMP-2 available for binding to the hemopexin-like domain of proMMP-2 (Zucker et al, 1998). This ternary complex clusters proMMP-2 near a TIMP-2-free MT1-MMP molecule on the cell surface. Free MT1-MMP cleaves the prodomain of proMMP-2 thus generating the $64-\mathrm{kDa}$ activation intermediate that then binds to $\alpha_{\mathrm{v}} \beta_{3}$ integrin and matures into the fully active $62-\mathrm{kDa}$ MMP-2. Localisation of active MMP- 2 and $\alpha_{v} \beta_{3}$ integrin at the migration front accelerates cancer cell migration (Brooks et al, 1996; Deryugina et al, 2001).

Basement membrane stores pro-invasive factors such as insulinlike growth factor (IGF), epidermal growth factor (EGF) and basic fibroblast growth factor (bFGF) which can stimulate the expression of MMP-2 and other MMPs (Mira et al, 1999; Zhang and Brodt 2003; Lee et al, 2004). Injuries to the basement membrane can result in the release of these pro-invasive compounds. Furthermore, fragmentation of matrix proteins by free radicals or limited proteolysis can generate biologically active peptides, that is, the matrikines (Vartio 1989; Monboisse and Borel 1992; Raats et al, 1997; Duca et al, 2004). Once released, these matrikines, such as elastin peptides, can increase the expression of MMP-2, MT1-MMP and TIMP-2 in fibrosarcoma HT-1080 cells (Brassart et al, 1998). Matrikines can also be derived from laminins, proteoglycans or collagens (Pasco et al, 2004).

In this study, we have determined whether irradiation of a reconstituted basement membrane (Matrigel; Becton Dickinson, Bedford, MA, USA) could enhance the expression of MMP-2, MT1MMP and TIMP-2 from breast cancer cells. Invasion chambers coated with Matrigel were irradiated prior to plate breast cancer cells and then the invasiveness of a highly metastatic breast carcinoma cell line, the MDA-MB-231 cells and of a weakly metastatic one, the MCF-7 cells were determined.

\section{MATERIALS AND METHODS}

\section{Chemicals and reagents}

p-Aminophenylmercuric acetate (APMA), Cell Dissociation Solution, diethyl pyrocarbonate (DEPC), DNase and gelatine were purchased from Sigma-Aldrich Canada Ltd (Oakville, Ontario, Canada). (2R)-[(4-biphenylylsulfonyl)amino]- $N$-hydroxy-3-phenylpropionamide, fluorogenic peptide MMP Substrate III, proMMP-2 and -9 were obtained from Calbiochem (San Diego, CA, USA). Matrigel (standard growth factors), invasion chambers and Cell Recovery Solution were obtained from BD Biosciences (Oakville, Ontario, Canada).

\section{Mammary cells culture}

The MDA-MB-231 and MCF-7 human breast cancer lines were obtained from American Type Culture Collection. Culture medium consisted of minimum essential medium (MEM) containing phenol red (Sigma, A-6770) and supplemented with $10 \%$ fetal bovine serum (FBS), penicillin $\left(10 \mathrm{U} \mathrm{ml}^{-1}\right)$, streptomycin $\left(10 \mu \mathrm{g} \mathrm{ml}^{-1}\right)$, amphotericin B $\left(0.25 \mu \mathrm{g} \mathrm{ml}^{-1}\right)$, L-glutamine $(2 \mathrm{mM})$ and sodium pyruvate $(1 \mathrm{~mm})$.

\section{Irradiation of Matrigel}

A volume of $500 \mu \mathrm{l}$ of Matrigel diluted in MEM medium without FBS at a final concentration of $5 \mathrm{mg} \mathrm{ml}^{-1}$ was added in six-well plate and allowed to polymerise for $1 \mathrm{~h}$ at $37^{\circ} \mathrm{C}$. Matrigel covered by $0.5 \mathrm{ml}$ of phosphate-buffered saline (PBS) was irradiated using the ${ }^{60} \mathrm{Co}$ source (Gammacell 220, Nordion, Canada) at the dose indicated. Non-irradiated Matrigel was used as control.

\section{RNA isolation}

Breast cancer cells were plated on either irradiated or nonirradiated Matrigel and incubated for $24 \mathrm{~h}$ in FBS-free culture medium. Cells were isolated with $1 \mathrm{ml}$ Cell Recovery Solution (Sigma) incubated at room temperature for $10 \mathrm{~min}$. Total RNA was isolated using the RNeasy Mini kit (QIAGEN, Mississauga, Canada) and then quantified in DEPC-treated water with a spectrophotometer. To reduce non-specific amplification, RNA samples were treated with the Amplification Grade DNase I kit (Sigma, Oakville, ON, Canada). Briefly, $1 \mu \mathrm{g}$ of RNA diluted in $8 \mu \mathrm{l}$ DEPC water was treated with $1 \mu \mathrm{l}$ Amplification Grade DNase I $\left(1 \mathrm{U}^{-1} \mathrm{l}^{-1}\right)$ in a final volume of $10 \mu \mathrm{l}$ completed with the reaction buffer $\left(20 \mathrm{~mm}\right.$ Tris- $\left.\mathrm{HCl} \mathrm{pH} 7.5,1 \mathrm{~mm} \mathrm{CaClB}_{2}\right)$. After $15 \mathrm{~min}$ incubation at room temperature, $1 \mu \mathrm{l}$ of the Stop solution $(50 \mathrm{~mm}$ EDTA) was added. The RNA samples were then heated at $70^{\circ} \mathrm{C}$ for 10 min to denature the DNase I.

\section{Real-time PCR}

cDNA was produced from the DNase I-treated RNA samples by adding to $1 \mu \mathrm{g}$ RNA, the reverse transcriptase M-MLV (200 U per $21 \mu \mathrm{l}$ ) (Bio Can Scientific Inc., Mississauga, ON, Canada), the RNase inhibitor RNAguard ${ }^{\mathrm{TM}}(2 \mathrm{U}$ per $21 \mu \mathrm{l})$ (Amersham Biosciences, Baie d'Urfe, Québec, Canada), the pd(N)6 (100 pmol $\left.\mu \mathrm{l}^{-1}\right)$ and the dNTPS (10 mM) (Amersham Pharmacia Biotech Inc., Piscataway, NJ, USA) in a final volume of $21 \mu \mathrm{l}$ completed with the reaction buffer (final concentrations: $50 \mathrm{~mm}$ Tris- $\mathrm{HCl} \mathrm{pH} 8.3$, $75 \mathrm{~mm} \mathrm{KCl}, 3 \mathrm{mM} \mathrm{Mgcl} 2,10 \mathrm{~mm}$ dithiothreitol). The reaction conditions were $20^{\circ} \mathrm{C}$ for $10 \mathrm{~min}, 42^{\circ} \mathrm{C}$ for $50 \mathrm{~min}$ and $95^{\circ} \mathrm{C}$ for $5 \mathrm{~min}$.

A total of $50 \mathrm{ng}$ of the cDNA product was used for real-time PCR. Amplification of each PCR product was carried out separately in a different tube. The primers used were MMP-2 $(71 \mathrm{pb})$ sense primer $5^{\prime}$-CGCTCAGATCCGTGGTGAG-3', antisense primer $5^{\prime}$-TTGTCACGTGGCGTCACAG-3' (Strup-Perrot et al, 2004); MT1-MMP (496pb) sense primer, $5^{\prime}$-CGCTACGCCATCCAG GGTCTCAAA- $3^{\prime}$, antisense primer $5^{\prime}$-CGGTCATCATCGGGCAGCACAAAA-3' (Daja et al, 2003); TIMP-2 (303pb) sense primer $5^{\prime}$ GGTCTCGCTGGACGTTGGAG-3', antisense primer $5^{\prime}$-GGAGCCG TCACTTCTCTTG-3' (Balduyck et al, 2000). As control, glyceraldehyde-3-phosphate dehydrogenase (GAPDH) (307pb) amplification was performed using the primers: sense $5^{\prime}$-CGGAGTCAACG GATTTGGTCGTAT- ${ }^{\prime}$, antisense $5^{\prime}$-AGCCTTCTCCATGGTGGTG AAGAC-3' (Wong et al, 2001).

Real-time PCR were performed using the detection kit Quantitect ${ }^{\mathrm{TM}}$ SYBR ${ }^{\circledR}$ Green PCR ${ }^{\circledR}$ (QIAGEN) under the following conditions. Reaction mixtures with primers at $10 \mathrm{pmol}^{-1} \mathrm{l}^{-1}$ were incubated in the thermocycler LightCycler (Roche Applied Science, Laval, Québec, Canada). All PCR programs started with $15 \mathrm{~min}$ at $95^{\circ} \mathrm{C}$ to activate the HotStarTaq ${ }^{\mathbb{R}}$ DNA polymerase. The specific conditions were MMP-2, $30 \mathrm{~s}$ at $94^{\circ} \mathrm{C}, 45 \mathrm{~s}$ at $52^{\circ} \mathrm{C}$ and $1 \mathrm{~min}$ at $72^{\circ} \mathrm{C}$; MT1-MMP, $30 \mathrm{~s}$ at $94^{\circ} \mathrm{C}, 30 \mathrm{~s}$ at $62^{\circ} \mathrm{C}$ and $1 \mathrm{~min}$ at $72^{\circ} \mathrm{C}$; 
TIMP-2 and GAPDH, $50 \mathrm{~s}$ at $94^{\circ} \mathrm{C}, 50 \mathrm{~s}$ at $55^{\circ} \mathrm{C}$ and $20 \mathrm{~s}$ at $72^{\circ} \mathrm{C}$. Amplifications were performed for a maximum of 45 cycles. Relative quantification was performed with the LightCycler ${ }^{\mathbb{R}}$ Software 4.0 according to the manufacturer's instructions and the method reported by Pfaffl (2001). Fusion curves were performed to eliminate the possibility of quantifying non-specific sequences. The PCR products were also analysed on $1.8 \%$ agarose gels to confirm that the right amplifications had been effectuated. DNA bands were stained with the fluorogen SYBR Green IP ${ }^{\circledR P}$ ${ }^{\mathrm{P}}$ (Molecular Probes, Burlington, Ontario, Canada) and analysed at $500 \mathrm{~nm}$ with the STORM ${ }^{\mathbb{R}} 860$ and the software ImagQuant ${ }^{\mathrm{TM}}$ (Molecular Dynamics Inc., Baie d’Urfe, Québec, Canada).

\section{Secretion of MMP-2 from cancer cells plated on irradiated Matrigel}

A volume of $500 \mu \mathrm{l}$ of Matrigel diluted in an MEM medium without FBS at a final concentration of $5 \mathrm{mg} \mathrm{ml}^{-1}$ was added to the six-well plate and allowed to polymerise for $1 \mathrm{~h}$ at $37^{\circ} \mathrm{C}$. Matrigel covered by $0.5 \mathrm{ml}$ of PBS was irradiated using the ${ }^{60} \mathrm{Co}$ source (Gammacell 220 , Nordion) at a dose of $20 \mathrm{~Gy}$. Non-irradiated Matrigel was used as control. MDA-MB-231 or MCF-7 breast cancer cells $\left(6 \times 10^{5}\right)$ were added on Matrigel in 10\% FBS MEM and incubated for $3 \mathrm{~h}$. Then the cells were washed twice using PBS, and incubated for $24 \mathrm{~h}$ in FBS-free culture medium. Conditioned media were obtained using FBS-free culture medium to eliminate the endogenous proMMPs found in FBS. The conditioned media were concentrated 20 times using the Centricon YM30 column (Millipore, Etobicoke, Ontario, Canada) and samples were then analysed on a zymography gel as previously described (Paquette et al, 2005). Zymography is a non-reducing acrylamide gel polymerised with an MMP-2 and MMP-9 Substrate, gelatine. It allows proMMP and MMP to be distinguished according to their molecular weights. Samples were applied on a $12 \%$ polyacrylamide-sodium dodecyl sulfate (SDS) gel containing $0.1 \%$ gelatine and electrophoresed at $150 \mathrm{~V}$ during $3 \mathrm{~h}$ at $4^{\circ} \mathrm{C}$. After removal of SDS from the gel by incubating in $2.5 \%$ Triton X-100 (30 min, four times), the gel was incubated at $37^{\circ} \mathrm{C}$ for $18 \mathrm{~h}$ in $40 \mathrm{~mm}$ Tris- $\mathrm{HCl}, \mathrm{pH} \mathrm{7.5,} \mathrm{containing}$ $10 \mathrm{mM} \mathrm{CaCl}_{2}, 1 \mu \mathrm{M} \mathrm{ZnCl}_{2}, 200 \mathrm{~mm} \mathrm{NaCl}$ and stained with Coomassie blue R-250 (Albini et al, 1995). As positive control, MMP-2 and -9 obtained from Calbiochem were activated with $1 \mathrm{mM}$ APMA as previously described (Paquette et al, 2003) and analysed by zymography. Briefly, $17 \mathrm{ng}$ of proMMPs were incubated in $10 \mu \mathrm{l}$ of buffer A (100 mM Tris-HCl pH 7.6, $150 \mathrm{~mm} \mathrm{NaCl}^{2} 5 \mathrm{mM} \mathrm{Cacl}_{2}, 1 \mu \mathrm{M}$ $\mathrm{Zncl}_{2}, 0.01 \%$ Brij 35) containing $1 \mathrm{mM} \mathrm{APMA}$ at $37^{\circ} \mathrm{C}$ for $2 \mathrm{~h}$. A stock solution of $10 \mathrm{mM}$ APMA was prepared in $0.1 \mathrm{~N} \mathrm{NaOH}$. MMPs activated by APMA were diluted 1:8 and then electrophoresed. Gels were scanned and analysed using ImageJ $1.34 \mathrm{n}$ (public domain Java image, NIH, Bethesda, MD, USA).

\section{Invasion chambers}

Invasion chambers coated with Matrigel were rehydrated with $1 \mathrm{ml}$ MEM $0.1 \%$. bovine serum albumin (BSA) for $1 \mathrm{~h}$ at $37^{\circ} \mathrm{C}$. Before cell plating, the chambers were irradiated at the indicated dose using a ${ }^{60}$ Co source (Gammacell 220, Nordion). MDA-MB-231 and MCF-7 breast cancer cells were harvested with $1 \mathrm{ml}$ of Cell Dissociation Solution (Sigma) incubated for $10 \mathrm{~min}$ at room temperature, washed with PBS, suspended in $1 \mathrm{ml}$ MEM $0.1 \%$ BSA, plated $\left(1 \times 10^{4}\right.$ or $4 \times 10^{4}$ in $\left.0.5 \mathrm{ml}\right)$ in the invasion chambers and then incubated at $37^{\circ} \mathrm{C}$ for $6 \mathrm{~h}$. In another series, breast cancer cells were treated in the invasion chambers with $0.1 \mathrm{~mm}$ of the MMP-2 inhibitor (2R)-[(4-biphenylylsulfonyl)amino]- $N$-hydroxy3-phenylpropionamide. To determine the role of MT1-MMP, breast cancer cells were mixed with an anti-MT1-MMP antibody (Fitzgerald Industries International Inc., catalogue no. RDIMMP14 HABR) at $20 \mu \mathrm{g} \mathrm{ml}^{-1}$ before plating in irradiated invasion chambers. As chemoattractant, MEM medium supplemented with
$10 \%$ FBS was added in the lower compartment of the invasion chamber. Cells, which have crossed the Matrigel and the porous membrane, were fixed, stained with $0.5 \%$ crystal violet and counted under the microscope.

To determine whether the enhancement of breast cancer cell invasion was caused by invasion factors released from irradiated Matrigel, four conditions were tested: (1) invasion through unirradiated Matrigel; (2) invasion through Matrigel which was irradiated without a layer of PBS before cell plating; (3) invasion through Matrigel which was irradiated with a layer of PBS $(0.2 \mathrm{ml})$ before cell plating and (4) invasion through unirradiated Matrigel where $0.2 \mathrm{ml}$ of conditioned PBS, isolated from an irradiated invasion chamber was added. This latter conditioned PBS covered the Matrigel of an invasion chamber during the irradiation. For the conditions 1 and 2, $0.2 \mathrm{ml}$ PBS was added just before cells plating.

\section{Irradiation of proMMP-2}

Cancer cells release inactive proMMP-2 which can be activated by free radicals, such as produced by the radiolysis of water (Saari et al, 1992; Paquette et al, 2003). To determine whether radiation could activate proMMP-2, aliquots $(0.17 \mu \mathrm{g})$ of this protease (Calbiochem) were irradiated using a ${ }^{60}$ Co source (Gammacell 220, Nordion) to a final dose of $20 \mathrm{~Gy}$ in the buffer used for the enzymatic assay. Conversion from proMMP-2 to active MMP-2 was monitored according to the cleavage of a fluorogenic peptide. Briefly, irradiated proMMP-2 was mixed in the reaction buffer A (50 mM borate pH 7.4, $5 \mathrm{mM} \mathrm{CaCl}_{2}, 20 \%$ glycerol, $0.005 \%$ Brij, $0.01 \mathrm{mM} \mathrm{ZnCl}_{2}$ ) to a final volume of $20 \mu \mathrm{l}$. The samples were then incubated with $50 \mu \mathrm{M}$ of the fluorogenic peptide MMP Substrate III (Calbiochem). The enzymatic activity was recorded according to the variation of RFU per sec. Care was taken to always work at the saturated concentration of the fluorogenic peptide. The kinetics of peptide cleavage were then followed for $30 \mathrm{~min}$ using the 96 -well plate reader Synergy HT (BioTek Instruments, Winooski, VT, USA) set at a $\lambda \mathrm{ex}=340 \mathrm{~nm}$ and a $\lambda \mathrm{em}=485 \mathrm{~nm}$. As a positive control, proMMP-2 was activated with $1 \mathrm{~mm}$ APMA as previously described (Paquette et al, 2003).

\section{MMP-2 activity from breast cancer cells surface}

MMP-2 activity on MDA-MB-231 and MCF-7 cells plated on irradiated Matrigel was measured using the fluorogenic peptide MMP Substrate III. Matrigel was irradiated at $20 \mathrm{~Gy}$ and then the breast cancer cells were plated and incubated for $18 \mathrm{~h}$ at $37^{\circ} \mathrm{C}$. The MEM $0.1 \%$ BSA was replaced by the enzymatic buffer A and the MMP-2 activity was measured by adding the fluorogenic peptide as previously described in the section 'Irradiation of proMMP-2'.

\section{Statistical analysis}

Data are expressed as the mean \pm standard deviation and analysed using a Student's $t$-test by comparing the experimental value to the non-irradiated control.

\section{RESULTS}

\section{Irradiated Matrigel enhances the expression of MMP-2, MT1-MMP and TIMP-2}

The coordinate expression of MMP-2, MT1-MMP and TIMP-2 is required for the activation of proMMP-2. A zymography gel was performed to determine whether irradiation of Matrigel (reconstituted basement membrane) can increase the secretion of MMP-2 from breast cancer cells. Petri dishes coated with Matrigel were irradiated at $20 \mathrm{~Gy}$ using a ${ }^{60} \mathrm{Co}$ irradiator. Two cell lines were tested: the MDA-MB-231 cells which are highly metastatic and the weakly metastatic MCF-7 cells. They were plated on Petri dishes 
after irradiation of Matrigel. The conditioned media were harvested $24 \mathrm{~h}$ later and MMP-2 was quantified by zymography gel. As a control, breast cancer cells were plated on non-irradiated Matrigel.

As shown in Figure 1A, irradiation of Matrigel at 20 Gy increased by about fourfold the level of proMMP-2 released into the culture media by MDA-MB-231 and MCF-7 breast cancer cells, compared to the non-irradiated controls. Conversely, the quantity of MMP-9 secreted under these conditions was negligible (Figure 1A).

Since proMMP-2 can be stored in Matrigel, the zymography was repeated to determine whether ionising radiation could induce the release of proMMP-2 from Matrigel. Our results showed that very few proMMP-2 was stored in Matrigel and radiation at $20 \mathrm{~Gy}$ resulted in only a slight increase of proMMP-2 released (Figure 1B lane $3 v s$ ). This data also confirmed that proMMP-2 was absent from the FBS-free culture media (Figure 1B, lane 2).

ProMMP-2 is activated on the surface of breast cancer cells by the MT1-MMP and TIMP-2. Their corresponding mRNA expressed by MDA-MB-231 and MCF-7 cells was quantified using a real-time PCR assay (Table 1). The expression of both MT1-MMP and TIMP2 by MDA-MB-231 cells plated on irradiated Matrigel were

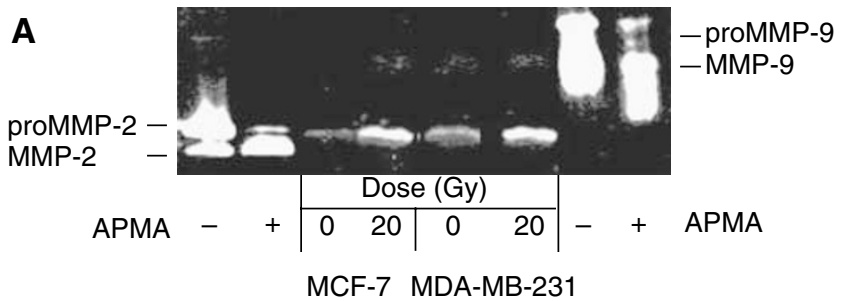

B

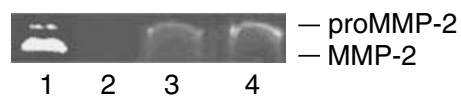

Figure I Irradiated Matrigel increased the secretion of matrix metalloproteinase (MMP)-2 from MDA-MB-23I and MCF-7 breast cancer cells. $(\mathbf{A})$ Cancer cells $\left(6 \times 10^{5}\right)$ were added on a layer of Matrigel which was previously irradiated using a ${ }^{60} \mathrm{Co}$ source at $20 \mathrm{~Gy}$. Non-irradiated Matrigel was used as control. After $24 \mathrm{~h}$ incubation, the culture media was removed, concentrated and analysed by zymogram electrophoresis gel. As controls, proMMP-2 and -9 obtained from Calbiochem were activated with p-aminophenylmercuric acetate (APMA) and the activated and unactivated forms were added to the zymogram gel. (B) MMP-2 released from Matrigel following irradiation. (I) proMMP-2 activated by APMA; (2) concentrated FBS-free culture media; (3) concentrated FBS-free culture media incubated for $24 \mathrm{~h}$ on non-irradiated Matrigel; and (4) concentrated FBS-free culture media incubated for $24 \mathrm{~h}$ on Matrigel previously irradiated at $20 \mathrm{~Gy}$. These assays were repeated four times. significantly increased by 3.07 -fold and 1.59 -fold, respectively. Conversely, MT1-MMP was not detectable in the weakly metastatic cells MCF-7, while the level of TIMP-2 was not significantly increased by the irradiated Matrigel. Regarding the MMP-2, its expression was stimulated in both cell lines plated on irradiated Matrigel, supporting the results obtained with the zymography analysis.

\section{Enhancement of MDA-MB-231 cells invasion capacity}

Invasion chambers were then used to determine whether irradiation of Matrigel can increase the invasiveness of breast cancer cells. Invasion chambers contain an $8 \mu \mathrm{m}$ pore-size membrane coated with Matrigel. MMPs can digest the Matrigel, which allows the invasion of cancer cells through the other side of the porous membrane. Prior to the addition of breast cancer cells, invasion chambers were irradiated using a ${ }^{60} \mathrm{Co}$ source at the dose indicated.

Results shown in Figure 2 were normalised according to the number of cells, which have crossed the Matrigel layer in absence of radiation. Our data demonstrated that irradiation of Matrigel at a dose as low as 5 Gy markedly increased the invasiveness of MDAMB-231 cells (Figure 2A). An enhancement of 7.5-fold was measured when the MDA-MB-231 cells were added at a concentration of $4 \times 10^{4}$ per $0.5 \mathrm{ml}$. At radiation doses higher than $5 \mathrm{~Gy}$, the number of cells crossing the Matrigel layer was too large to be accurately counted. Conversely, no enhancement of invasion following Matrigel irradiation was observed for the weakly metastatic MCF-7 cells.

To determine the effect of higher radiation dose on the invasiveness of breast cancer cells, the assay was repeated at a lower concentration of cancer cells, that is, $1 \times 10^{4}$ cells per $0.5 \mathrm{ml}$

Table I Effects of irradiated Matrigel on MMP-2, MTI-MMP and TIMP-2 expression

\begin{tabular}{lcc}
\hline & \multicolumn{2}{c}{ Enhancement ratio (20 Gy per $\mathbf{0}$ Gy $\left.\mathbf{y}^{\mathbf{a}}\right)$} \\
\cline { 2 - 3 } & MDA-MB-23 I & MCF-7 \\
\hline MMP-2 & $3.90( \pm 0.28)^{*}$ & $1.58( \pm 0.16)^{*}$ \\
MTI-MMP & $3.07( \pm 0.11)^{*}$ & $\mathrm{ND}$ \\
TIMP-2 & $1.59( \pm 0.30)^{*}$ & $1.40( \pm 0.30)$ \\
\hline
\end{tabular}

The levels of mRNA were normalized according to the internal standard GAPDH. The enhancement ratio was calculated by dividing the normalized level measured at 20 Gy by the level at 0 Gy. Data represent the average of 4-6 assays \pm standard deviation. MMP-2 = matrix metalloproteinase-2; MTI-MMP=membrane type I matrix metalloproteinase; TIMP-2 = tissue inhibitor of metalloproteinase-2; $\mathrm{ND}=$ not detected. ${ }^{*} n=4-6 . P<0.05$.
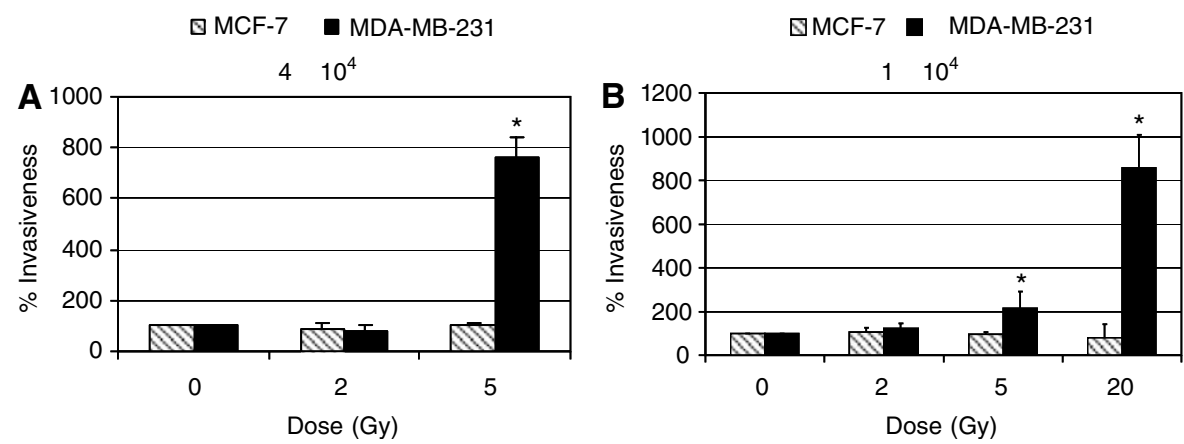

Figure 2 Enhancement of invasiveness induced by ionising radiation. Matrigel coated in the invasion chambers was irradiated using a ${ }^{60} \mathrm{Co}$ source. MDAMB-23I and MCF-7 cells $\left(\mathbf{A}: 4 \times 10^{4}\right.$ or $\left.\mathbf{B}: 1 \times 10^{4}\right)$ were added on the Matrigel after the irradiation and then incubated for $6 \mathrm{~h}$ in MEM $0.1 \%$ BSA. MDAMB-23I cells: ${ }^{*} n=4$; 0 vs 5 Gy: $P=0.05 ; 0$ vs 20 Gy: $P=0.0004$. 
(Figure $2 \mathrm{~B}$ ). At a radiation dose of $5 \mathrm{~Gy}$, the invasion of MDA-MB231 cells still increased by about twofold, while an enhancement of 8.5 -fold was obtained following an irradiation at $20 \mathrm{~Gy}$. The higher enhancement of radiation-induced invasion at $5 \mathrm{~Gy}$ observed after plating $4 \times 10^{4}$ compared to $1 \times 10^{4}$ cells was suggested to be associated with a higher quantity of MMP-2 secreted by the MDAMB-231 cells. As previously measured, the enhancement of invasiveness was observed only with the MDA-MB-231 cells since irradiation of Matrigel did not modify the invasion capacity of the low metastatic MCF-7 cells.

The real-time PCR assay has demonstrated that irradiated Matrigel increased the expression of MMP-2 and MT1-MMP. To further investigate the role of theses MMPs in radiation enhancement of invasion, the invasion assay was repeated in presence of either an MMP-2 inhibitor, the (2R)-[(4-biphenylylsulfonyl)amino]-N-hydroxy-3-phenylpropionamide or an anti-MT1-MMP antibody $\left(20 \mu \mathrm{g} \mathrm{ml}^{-1}\right)$. As shown in Figure 3, both the MMP-2 inhibitor and anti-MT1-MMP antibody significantly prevented the enhancement of MDA-MB-231 cells invasion induced by ionising radiation.

\section{Release of pro-invasive factors from irradiated Matrigel}

Some modifications to Matrigel can be produced by the direct interaction of radiation with Matrigel. On the other hand, the radiolysis of water generates free radicals, which can also damage the Matrigel. To determine the importance of these pathways, invasion chambers were irradiated with or without a layer of PBS added on the Matrigel. As seen in Table 2, irradiation of invasion chambers without PBS has increased by fourfold the number of MDA-MB-231 cells that have crossed the Matrigel, compared to data obtained with non-irradiated invasion chambers (condition no. 1 vs 2). This enhancement of the invasiveness of the breast cancer cells was further increased when the invasion chambers were covered by a layer of PBS during exposure to radiation, that is, an 8.5-fold increase compared to non-irradiated control (condition no. 1 vs 3). These data suggest that ionising radiation does induce some modification of the Matrigel, which enhances the invasiveness of MDA-MB-231 cells.

The invasion assay was then repeated to determine whether proinvasive factors stored in the Matrigel could be released by the ionising radiation. To verify this hypothesis, invasion chambers covered by a layer of PBS were irradiated. These conditioned PBS

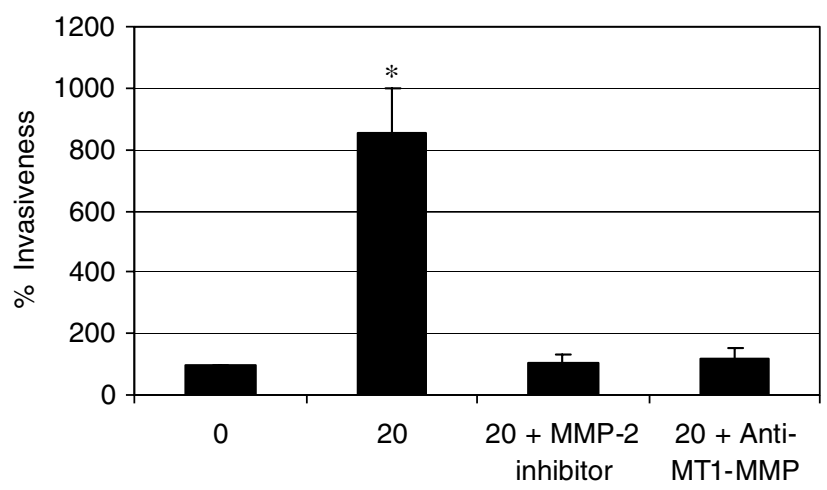

Radiation dose (Gy)

Figure 3 A matrix metalloproteinase (MMP)-2 inhibitor or an antimembrane type I matrix metalloproteinase (MTI-MMP) antibody prevented radiation enhancement of MDA-MB-23I breast cancer cell invasion. MDA-MB-23I cancer cells were mixed with either the MMP-2 inhibitor (2R)-[(4-biphenylylsulfonyl)amino]-N-hydroxy-3-phenylpropionamide at $0.1 \mathrm{mM}$, or an anti-MTI-MMP antibody $\left(20 \mu \mathrm{g} \mathrm{ml}^{-1}\right)$ before plating in the invasion chamber which was previously irradiated at $20 \mathrm{~Gy} \cdot{ }^{*} n=3$, $P<0.05$. were then transferred to new invasion chambers, where MDA-MB231 cells were then added (condition no. 4). As seen in Table 2, conditioned PBS isolated from irradiated Matrigel increased by more than eightfold the number of MDA-MB-231 cells that have crossed the Matrigel compared to non-irradiated invasion chambers (condition no. 1 vs 4). These data suggest that ionising radiation can induce the release of pro-invasive factors stored in Matrigel, which can enhance the invasiveness of MDA-MB-231 breast cancer cells.

\section{Enhancement of MMP-2 activity on breast cancer cells surface}

Irradiated Matrigel increases the expression of MMP-2 as shown by an enhancement of its mRNA and the release of proMMP-2 protein in culture media. We have also determined whether the activity of MMP-2 on the cell membrane of MDA-MB-231 and MCF-7 cells was also increased. The two cell lines were plated on irradiated Matrigel and incubated for $18 \mathrm{~h}$. A fluorogenic peptide cleaved by MMP-2 was then added. Our data demonstrate that irradiation of Matrigel leads to a 4.5-fold increase of MMP-2 activity on the surface of MDA-MB-231 cells, while no MMP-2 activity was measured on the MCF-7 cells (Figure 4).

\section{Radiation alone did not convert proMMP-2 into active MMP-2}

Radiolysis of water by ionising radiation generates the free radicals $\mathrm{O}_{2}{ }^{-}$and ${ }^{\circ} \mathrm{OH}$. Studies in our laboratory and elsewhere have shown that these free radicals can convert proMMP-2 into active MMP-2 (Saari et al, 1992; Paquette et al, 2003). Therefore, assays were carried out to determine whether ionising radiation at a dose of $20 \mathrm{~Gy}$ could lead to the activation of proMMP-2. The level of MMP2 activation was determined using a fluorogenic peptide. In parallel, MMP-2 activated by APMA was used as a positive control.

As shown in Figure 5A, a dose of $20 \mathrm{~Gy}$ did not lead to a detectable activation of proMMP-2. The enzymatic assay was working, as determined after activation of proMMP-2 by the activator APMA. To rule out the possibility that radiation might degrade MMP-2 after the cleavage of the propeptide, active MMP-2 was exposed to $60 \mathrm{~Gy}$. No loss of MMP-2 activity was measured confirming that radiation did not degrade the active MMP-2 (Figure 5B).

Table 2 Effect of Matrigel irradiation on the invasiveness of MDA-MB23I cells

\begin{tabular}{|c|c|c|c|}
\hline No. & $\begin{array}{l}\text { Dose } \\
\text { (Gy) }\end{array}$ & Conditions & $\begin{array}{c}\text { Average number } \\
\text { of cells migrating } \\
\text { through } \\
\text { Matrigel (s.d.) }\end{array}$ \\
\hline । & 0 & No irradiation & $6.3( \pm 2.3)$ \\
\hline 2 & 20 & Invasion chamber irradiated without PBS & $24.0( \pm 9.6) *$ \\
\hline 3 & 20 & Invasion chamber irradiated with PBS & $54.0( \pm 13.0) *$ \\
\hline 4 & 0 & $\begin{array}{l}\text { PBS was removed after irradiation of } \\
\text { Matrigel and then added to new } \\
\text { non-irradiated chambers before } \\
\text { cells plating }\end{array}$ & $57.0( \pm 28.6) *$ \\
\hline
\end{tabular}

PBS = phosphate-buffered saline; s.d. = standard deviation. Invasion chambers were treated as indicated. MDA-MB-23 I cells $\left(1 \times 10^{4}\right)$ were added after irradiation of the invasion chambers and incubated for $6 \mathrm{~h}$ in MEM 0.1\% BSA. The same volume of PBS was added to the other invasion chambers (condition nos. I, 2 and 4) before cells plating. ${ }^{*} n=3$. Student's- $t$ test: condition no. I vs $2, P=0.003$; condition no. I vs 3 , $P=0.026$; conditions no. I vs $4, P=0.023$. ${ }^{a}$ Average number of invasive cells observed per microscope field. 


\section{DISCUSSION}

After breast-conserving surgery, 39-63\% of patients have additional malignant foci scattered throughout the breast (Lagios et al, 1981; Holland et al, 1985). Radiation therapy after surgery consists typically of irradiation of the whole breast with $50-60 \mathrm{~Gy}$, delivered over 6 weeks. However, the radiation dose is not calculated to eliminate all residual cancer cells. Rather, the radiation dose is calculated to optimise the long-term results with minimal complications (Coles et al, 2005). The overall aim of this study was to determine whether ionising radiation could increase the invasion ability of breast cancer cells.

Radiation enhancement of cancer cell invasiveness has already been reported for other cancers. In vitro irradiation of human glioma cells increased the expression of MMP-2 and enhanced their invasiveness (Wild-Bode et al, 2001; Park et al, 2006; Zhai et al, 2006). Sublethal in vitro irradiation of rat 9L glioma cells resulted in the formation of a greater number of tumour satellites after injection of these irradiated cells into the striatum of rat brain. The ability of radiation to increase the expression of some MMPs and the invasiveness of cancer cells have also been reported for pancreatic cancer cells (Qian et al, 2002; Ohuchida et al, 2004), melanoma cells (Kaliski et al, 2005), rectal carcinoma cells (Speake et al, 2005), colon carcinoma cells and osteosarcoma cells (Wang et al, 2000).

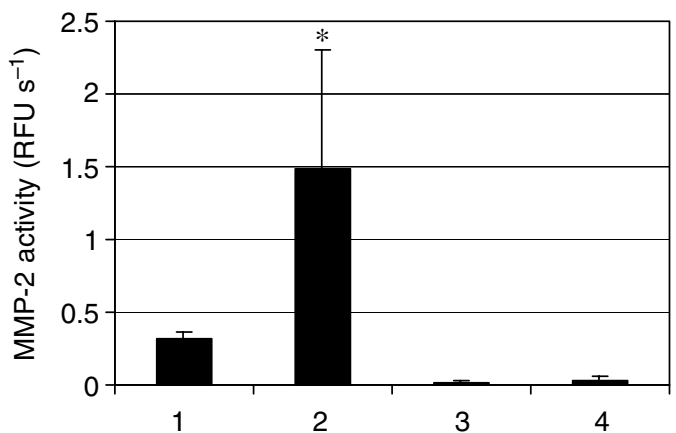

Figure 4 Matrix metalloproteinase (MMP)-2 activity on MDA-MB-23। and MCF-7 cells plated on irradiated Matrigel. Matrigel was irradiated at 0 or $20 \mathrm{~Gy}$ and the MDA-MB-23I or MCF-7 cells were plated and incubated for $18 \mathrm{~h}$ at $37^{\circ} \mathrm{C}$. Then the MEM $0.1 \%$ BSA was replaced by the enzymatic buffer $A$ and the MMP-2 activity was measured by adding the fluorogenic peptide MMP Substrate III. (I) MDA-MB-23I cells and O Gy; (2) MDA-MB23 I cells and $20 \mathrm{~Gy} ;$ (3) MCF-7 and 0 Gy and (4) MCF-7 and $20 \mathrm{~Gy}$. ${ }^{*} n=3$, $P<0.05$.
Cancer cells in the breast are surrounded by the basement membrane, which plays an important role in regulating the expression of numerous genes. In this study, we wanted to determine whether irradiation of Matrigel (a reconstituted basement membrane) could modify the invasive behaviour of breast cancer cells.

Using invasion chambers, we have demonstrated that in vitro irradiation of Matrigel at a dose as low as $5 \mathrm{~Gy}$ before cells plating enhanced the invasiveness of the highly metastatic MDA-MB-231 breast cancer cells. This radiation enhancement of invasion was associated with the upregulation of pro-invasive gene MMP-2. Indeed, irradiation of Matrigel before plating the cancer cells resulted in an enhancement of proMMP-2 secreted from the two breast cancer cell lines tested in the culture media, as detected using a zymography gel. This enhancement was associated with an increase of MMP-2 mRNA in both cell lines, as quantified by realtime PCR. Supporting the role of MMP-2, radiation enhancement of breast cancer cell invasion was prevented by an MMP-2 inhibitor. These results support the importance of the interactions between breast cancer cells and irradiated Matrigel for the expression of MMP-2.

MT1-MMP and TIMP-2 are required for the conversion of inactive proMMP-2 into active MMP-2. The activation intermediate of MMP-2 matures after binding to $\alpha_{v} \beta_{3}$ integrin which is localised at the cancer cell surface and concentrated at the migrating front (Brooks et al, 1996). Irradiated Matrigel increased the expression of both MT1-MMP and TIMP-2, as measured by real-time PCR, and increased MMP-2 activity on the surface of MDA-MB-231 cells. Supporting the role of MT1-MMP, the radiation enhancement of MDA-MB-231 cell invasion was prevented by mixing the cancer cells with an anti-MT1-MMP antibody before plating in the irradiated invasion chamber.

Conversely, no enhancement of invasiveness was observed with the low metastatic MCF-7 cell line. This latter result supports the concept that radiation did not create 'holes' in Matrigel, which would facilitate the migration of breast cancer cells. The inability of radiation to enhance the invasion of MCF-7 cells was associated with the absence of MT1-MMP expression, which is required to activate proMMP-2. The MCF-7 cells do not also express the $\alpha_{\mathrm{v}} \beta_{3}$ integrin (Deryugina et al, 1996) and consequently no MMP-2 activity was detected on surface of this breast cancer cell line. These results suggest that the expression of MT1-MMP is required for the enhancement of breast cancer cell invasion induced by irradiating the Matrigel.

The radiation enhancement of breast cancer cell invasion reported in this study could be related to two pathways. The stimulation of the expression of various MMPs by damaged
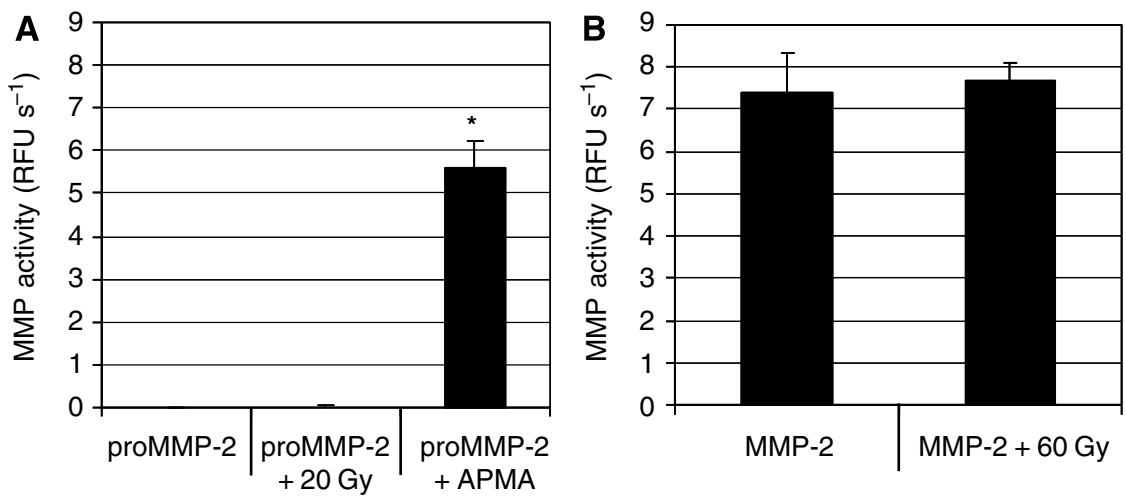

Figure 5 Inability of ionising radiation to directly activate the proMMP-2. (A) ProMMP-2 obtained from Calbiochem was irradiated at 20 Gy. As positive control, proMMP-2 was activated by p-aminophenylmercuric acetate (APMA). (B) Active MMP-2 was irradiated at $60 \mathrm{~Gy}$. The level of matrix metalloproteinase (MMP) activity was determined using the fluorogenic peptide MMP Substrate III. $*_{n}=6, P<0.05$. 
basement membrane is a normal process observed during wound healing (Gillard et al, 2004). Following damage to basement membrane by chemical or physical agents, the production of MMPs by fibroblasts is stimulated resulting in the remoulding and the restoration of basement membrane. The stimulation of MMPs expression is related to the following mechanisms. Basement membrane stores pro-invasive factors such as IGF, EGF and bFGF. These growth factors can be released by agents, which damage the basement membrane. Once released, they can stimulate the expression of MMP-2 and other MMPs (Mira et al, 1999; Zhang and Brodt 2003; Lee et al, 2004). Our results support the idea that the radiation enhancement of cancer cell invasion was related to the release of pro-invasive factors stored in the Matrigel. Indeed, we have shown that the transfer of conditioned PBS, which was covering the Matrigel during the irradiation, to new non-irradiated invasion chambers resulted in an eightfold increase of MDA-MB231 cells invasiveness.

An alternative explanation might be that basement membrane is a source of matrikines, which can be unmasked after limited proteolysis or cleavage by free radicals, as generated by ionising radiation. In an adult organism in the resting state, there is little MMP expression and activity (Bosman and Stamenkovic 2003).

\section{REFERENCES}

Albini A, D’Agostini F, Giunciuglio D, Paglieri I, Balansky R, De Flora S (1995) Inhibition of invasion, gelatinase activity, tumor take and metastasis of malignant cells by $\mathrm{N}$-acetylcysteine. Int $\mathrm{J}$ Cancer 61: $121-129$

Archambeau JO, Pezner R, Wasserman T (1995) Pathophysiology of irradiated skin and breast. Int J Radiat Oncol Biol Phys 31: 1171-1185

Balduyck M, Zerimech F, Gouyer V, Lemaire R, Hemon B, Grard G, Thiebaut C, Lemaire V, Dacquembronne E, Duhem T, Lebrun A, Dejonghe MJ, Huet G (2000) Specific expression of matrix metalloproteinases 1, 3, 9 and 13 associated with invasiveness of breast cancer cells in vitro. Clin Exp Metastasis 18: 171-178

Belkhiri A, Richards C, Whaley M, McQueen SA, Orr FW (1997) Increased expression of activated matrix metalloproteinase- 2 by human endothelial cells after sublethal $\mathrm{H} 2 \mathrm{O} 2$ exposure. Lab Invest 77: $533-539$

Bosman FT, Stamenkovic I (2003) Functional structure and composition of the extracellular matrix. J Pathol 200: 423-428

Brassart B, Randoux A, Hornebeck W, Emonard H (1998) Regulation of matrix metalloproteinase-2 (gelatinase A, MMP-2), membrane-type matrix metalloproteinase-1 (MT1-MMP) and tissue inhibitor of metalloproteinases-2 (TIMP-2) expression by elastin-derived peptides in human HT-1080 fibrosarcoma cell line. Clin Exp Metastasis 16: 489-500

Brooks PC, Stromblad S, Sanders LC, von Schalscha TL, Aimes RT, StetlerStevenson WG, Quigley JP, Cheresh DA (1996) Localization of matrix metalloproteinase MMP-2 to the surface of invasive cells by interaction with integrin alpha v beta 3. Cell 85: 683-693

Clarke M, Collins R, Darby S, Davies C, Elphinstone P, Evans E, Godwin J, Gray R, Hicks C, James S, MacKinnon E, McGale P, McHugh T, Peto R, Taylor C, Wang Y (2005) Effects of radiotherapy and of differences in the extent of surgery for early breast cancer on local recurrence and 15-year survival: an overview of the randomised trials. Lancet 366: 2087-2106

Coles CE, Moody AM, Wilson CB, Burnet NG (2005) Reduction of radiotherapy-induced late complications in early breast cancer: the role of intensity-modulated radiation therapy and partial breast irradiation. Part I-normal tissue complications. Clin Oncol (R Coll Radiol) 17: 16-24

Daja MM, Niu X, Zhao Z, Brown JM, Russell PJ (2003) Characterization of expression of matrix metalloproteinases and tissue inhibitors of metalloproteinases in prostate cancer cell lines. Prostate Cancer Prostatic Dis 6: $15-26$

Deryugina EI, Ratnikov B, Monosov E, Postnova TI, DiScipio R, Smith JW, Strongin AY (2001) MT1-MMP initiates activation of pro-MMP-2 and integrin alphavbeta3 promotes maturation of MMP-2 in breast carcinoma cells. Exp Cell Res 263: 209-223

Deryugina EI, Strongin A, Yu C, Bourdon MA (1996) A novel monoclonal antibody, L1A3, is directed to the functional site of the alpha $v$ integrin subunit. Hybridoma 15: 279-288
However, basement membrane fragments or matrikines unmasked by tissue injury can upregulate the expression of MMPs. For example, the $\gamma 2$ subunit DIII fragment of laminin-5 can bind to the cell surface of MDA-MB-231 breast cancer cells and upregulate the expression of MMP-2 and -9 resulting in an increase migratory activity (Schenk et al, 2003). The involvement of these two mechanisms in radiation enhancement of cancer cell invasion deserves to be tested in subsequent studies.

Radiotherapy is an efficient modality to treat malignant breast tumours and other types of solid tumours. However, the present study and previous reports published by other teams demonstrate that radiation can also increase the invasion capacity of cancer cells. To improve the efficacy of radiotherapy, this phenomenon must be further studied to elaborate therapeutic modalities to prevent radiation enhancement of cancer cell invasion.

\section{ACKNOWLEDGEMENTS}

This research project was funded by the Canadian Breast Cancer Alliance of Canada, grant no. 013306.
Duca L, Floquet N, Alix AJ, Haye B, Debelle L (2004) Elastin as a matrikine. Crit Rev Oncol Hematol 49: 235-244

Fillmore HL, VanMeter TE, Broaddus WC (2001) Membrane-type matrix metalloproteinases (MT-MMPs): expression and function during glioma invasion. J Neurooncol 53: 187-202

Frazier TG, Wong RW, Rose D (1989) Implications of accurate pathologic margins in the treatment of primary breast cancer. Arch Surg 124: $37-38$

Gillard JA, Reed MW, Buttle D, Cross SS, Brown NJ (2004) Matrix metalloproteinase activity and immunohistochemical profile of matrix metalloproteinase-2 and -9 and tissue inhibitor of metalloproteinase-1 during human dermal wound healing. Wound Repair Regen 12: 295-304

Gilles C, Bassuk JA, Pulyaeva H, Sage EH, Foidart JM, Thompson EW (1998) SPARC/osteonectin induces matrix metalloproteinase 2 activation in human breast cancer cell lines. Cancer Res 58: 5529-5536

Holland R, Veling SH, Mravunac M, Hendriks JH (1985) Histologic multifocality of Tis, T1-2 breast carcinomas. Implications for clinical trials of breast-conserving surgery. Cancer 56: $979-990$

Jones JL, Glynn P, Walker RA (1999) Expression of MMP-2 and MMP-9, their inhibitors, and the activator MT1- MMP in primary breast carcinomas. J Pathol 189: $161-168$

Kaliski A, Maggiorella L, Cengel KA, Mathe D, Rouffiac V, Opolon P, Lassau N, Bourhis J, Deutsch E (2005) Angiogenesis and tumor growth inhibition by a matrix metalloproteinase inhibitor targeting radiationinduced invasion. Mol Cancer Ther 4: 1717-1728

Lagios MD, Westdahl PR, Rose MR (1981) The concept and implications of multicentricity in breast carcinoma. In: Pathology Annual, Sommers SRosen P (eds). New York: Appleton-Century-Crofts

Lee YM, Bae MH, Lee OH, Moon EJ, Moon CK, Kim WH, Kim KW (2004) Synergistic induction of in vivo angiogenesis by the combination of insulin-like growth factor-II and epidermal growth factor. Oncol Rep 12: $843-848$

Liotta LA, Stetler-Stevenson WG (1991) Tumor invasion and metastasis: an imbalance of positive and negative regulation. Cancer Res 51: 5054s5059s

Mira E, Manes S, Lacalle RA, Marquez G, Martinez AC (1999) Insulin-like growth factor I-triggered cell migration and invasion are mediated by matrix metalloproteinase-9. Endocrinology 140: 1657-1664

Monboisse JC, Borel JP (1992) Oxidative damage to collagen. Exs 62: $323-327$

Ohuchida K, Mizumoto K, Murakami M, Qian LW, Sato N, Nagai E, Matsumoto K, Nakamura T, Tanaka M (2004) Radiation to stromal fibroblasts increases invasiveness of pancreatic cancer cells through tumor - stromal interactions. Cancer Res 64: 3215-3222

Paquette B, Bisson M, Baptiste C, Therriault H, Lemay R, Cantin AM (2005) Invasiveness of breast cancer cells MDA-MB-231 through extracellular 
matrix is increased by the estradiol metabolite 4-hydroxyestradiol. Int $J$ Cancer 113: $706-711$

Paquette B, Bisson M, Therriault H, Lemay R, Pare M, Banville P, Cantin AM (2003) Activation of matrix metalloproteinase-2 and -9 by 2- and 4hydroxyestradiol. J Steroid Biochem Mol Biol 87: 65-73

Park CM, Park MJ, Kwak HJ, Lee HC, Kim MS, Lee SH, Park IC, Rhee CH, Hong SI (2006) Ionizing radiation enhances matrix metalloproteinase-2 secretion and invasion of glioma cells through Src/epidermal growth factor receptor-mediated p38/Akt and phosphatidylinositol 3-kinase/Akt signaling pathways. Cancer Res 66: 8511-8519

Pasco S, Ramont L, Maquart FX, Monboisse JC (2004) Control of melanoma progression by various matrikines from basement membrane macromolecules. Crit Rev Oncol Hematol 49: 221-233

Pfaffl MW (2001) A new mathematical model for relative quantification in real-time RT-PCR. Nucleic Acids Res 29: e45

Qian LW, Mizumoto K, Urashima T, Nagai E, Maehara N, Sato N, Nakajima M, Tanaka M (2002) Radiation-induced increase in invasive potential of human pancreatic cancer cells and its blockade by a matrix metalloproteinase inhibitor, CGS27023. Clin Cancer Res 8: 1223-1227

Raats CJ, Bakker MA, van den Born J, Berden JH (1997) Hydroxyl radicals depolymerize glomerular heparan sulfate in vitro and in experimental nephrotic syndrome. J Biol Chem 272: 26734-26741

Rooprai HK, McCormick D (1997) Proteases and their inhibitors in human brain tumours: a review. Anticancer Res 17: 4151-4162

Saari H, Sorsa T, Lindy O, Suomalainen K, Halinen S, Konttinen YT (1992) Reactive oxygen species as regulators of human neutrophil and fibroblast interstitial collagenases. Int J Tissue React 14: 113-120

Schenk S, Hintermann E, Bilban M, Koshikawa N, Hojilla C, Khokha R, Quaranta V (2003) Binding to EGF receptor of a laminin-5 EGF-like fragment liberated during MMP-dependent mammary gland involution. J Cell Biol 161: 197-209

Silverstein MJ, Gierson ED, Colburn WJ, Cope LM, Furmanski M, Senofsky GM, Gamagami P, Waisman JR (1994) Can intraductal breast carcinoma be excised completely by local excision? Clinical and pathologic predictors. Cancer 73: 2985-2989

Speake WJ, Dean RA, Kumar A, Morris TM, Scholefield JH, Watson SA (2005) Radiation induced MMP expression from rectal cancer is short lived but contributes to in vitro invasion. Eur J Surg Oncol 31: 869-874

Strup-Perrot C, Mathé D, Linard C, Violot D, Milliat F, François A, Bourhis J, Vozenin-Brotons MC (2004) Global gene expression profiles reveal an increase in mRNA levels of collagens, MMPs and TIMPs in late radiation enteritis. Am J Physiol Gastrointest Liver Physiol 287: G875-G885

Vartio T (1989) Regular fragmentation of hydrogen peroxide-treated fibronectin. J Biol Chem 264: 4471-4475

Wang JL, Sun Y, Wu S (2000) Gamma-irradiation induces matrix metalloproteinase II expression in a p53-dependent manner. Mol Carcinog 27: 252-258

Wild-Bode C, Weller M, Rimner A, Dichgans J, Wick W (2001) Sublethal irradiation promotes migration and invasiveness of glioma cells: implications for radiotherapy of human glioblastoma. Cancer Res 61: 2744-2750

Wong H, Muzik H, Groft LL, Lafleur MA, Matouk C, Forsyth PA, Schultz GA, Wall SJ, Edwards DR (2001) Monitoring MMP and TIMP mRNA expression by RT-PCR. In: Matrix metalloproteinase protocols Methods in Molecular Biology Ian M Clark (ed). 151: 305-320. Humana Press

Zhai GG, Malhotra R, Delaney M, Latham D, Nestler U, Zhang M, Mukherjee N, Song Q, Robe P, Chakravarti A (2006) Radiation enhances the invasive potential of primary glioblastoma cells via activation of the Rho signaling pathway. J Neurooncol 76: $227-237$

Zhang D, Brodt P (2003) Type 1 insulin-like growth factor regulates MT1MMP synthesis and tumor invasion via PI 3-kinase/Akt signaling. Oncogene 22: $974-982$

Zucker S, Drews M, Conner C, Foda HD, DeClerck YA, Langley KE, Bahou WF, Docherty AJ, Cao J (1998) Tissue inhibitor of metalloproteinase-2 (TIMP-2) binds to the catalytic domain of the cell surface receptor, membrane type 1-matrix metalloproteinase 1 (MT1-MMP). J Biol Chem 273: $1216-1222$ 